\title{
Pengaruh Kinerja Guru Terhadap Motivasi Belajar IPA Berbasis Pendidikan Jarak Jauh pada Kelas Awal
}

\author{
Irvin Novita Arifin ${ }^{\natural}{ }^{\bowtie}$, Rifda Mardian Arif ${ }^{1}$, Indriyani Rauf ${ }^{1}$, Tasya Khairunnisa Habbibie ${ }^{1}$ \\ Pendidikan Guru Sekolah Dasar, Universitas Negeri Gorontalo, Indonesia(1)
}

DOI: $\underline{10.31004 / o b s e s i . v 6 i 3.1937}$

\begin{abstract}
Abstrak
Penelitian ini bertujuan untuk mengukur pengaruh Kinerja Guru Terhadap Motivasi Belajar siswa kelas awal Pada Pembelajaran IPA Berbasis Pembelajaran Jarak Jauh (PJJ) di Sekolah Dasar Negeri 77 Kota Tengah Kota Gorontalo. Dalam penelitian ini unsur kebaruan adalah variabel Y berupa motivasi kelas awal pada pembelajaran IPA berbasis Pembelajaran Jarak Jauh sehingga Hipotesis dalam penelitian ini adalah terdapat pengaruh langsung positif kinerja guru terhadap motivasi belajar siswa kelas awal pada pembelajaran ipa berbasis Pembelajaran Jarak Jauh (PJJ)". Penelitian ini dilakukan dalam bentuk Survei, data dikumpulkan melalui siswa yang terpilih sebagai anggota sampel dengan menggunakan instrumen angket yang disusun khusus untuk penelitian ini, metode survei yang digunakan dalam penelitian ini adalah metode survei kausal yang sifatnya menjelaskan hubungan dengan teknik analisis jalur. Variabel dalam penelitian initerdiri dari variabel bebas (eksogen) dan variabel terikat (endogen). Variabel dalam penelitian initerdiri eksogen berupa Kinerja guru (X). Sedangkan variabel terikat (endogen) yaitu berupa Motivasi Belajar (Y). Populasi dan sampel dalam penelitian ini adalah seluruh siswa kelas awal di SDN no. 77 Kota Tengah, hal ini menunjukkan bahwa eksistensi kinerja guru dipandang sebagai bagian yang paling penting dalam meningkatkan motivasi belajar siswa kelas awal pada pembelajaran IPA berbasis pendidikan jarak jauh.
\end{abstract}

Kata Kunci: kinerja guru; motivasi belajar; pembelajaran ipa.

\begin{abstract}
This study aims to measure the influence of teacher performance on learning motivation of early grade students in distance learning-based science learning (PJJ) in 77 State Elementary School, Central City, Gorontalo City. The hypothesis in this study is that there is a direct positive effect of teacher performance on the learning motivation of early grade students in distance learning-based science learning (PJJ). This research was conducted in the form of a survey. Data was collected through students selected as sample members using a questionnaire instrument specially prepared for this research. The survey method used in this study was a causal survey method that describes the relationship with path analysis techniques. The variables in this study consisted of the independent variable (exogenous) and the dependent variable (endogenous). The variables in this study consisted of exogenous teacher performance $(X)$. While the dependent variable (endogenous) is in the form of Learning Motivation (Y). The population and sample in this study were all early grade students at SDN no. 77 Central City.

Keywords: teacher performance; motivation to learn; science learning.
\end{abstract}

Copyright (c) 2021 Irvin Novita Arifin, et al.

$\square$ Corresponding author :

Email Address : irvinnovitaarifin@ung.ac.id (Gorontalo, Indonesia)

Received 9 July 2021, Accepted 13 December 2021, Published 31 December 2021 


\section{PENDAHULUAN}

Pada penelitian sebelumnya salah satu faktor penentu keberhasilan proses belajar mengajar khususnya diperguruan tinggi adalah kinerja dosen. Kinerja merupakan kemampuan dalam menunaikan tugas dan tanggung jawabnya sehingga mencapai tujuan yang diharapkan berdasarkan standar yang telah ditetapkan. Dosen merupakan ujung tombak keberhasilan pendidikan karena sebagai pendidik dosen mengemban amanah untuk mengembangkan potensi yang dimiliki mahasiswa, baik dari aspek pengetahuan, keterampilan, dan sikap yang sesuai dengan tujuan yang telah ditetapkan oleh karena itu sangat penting dalam perkuliahan konsep dasar IPA 2 dosen memiliki kinerja yang sesuai standar yang telah ditetapkan agar hasil belajar mahasiswa pada mata kuliah konsep dasar IPA 2 dapat meningkat (Cahyono, 2012; Mudjihartono et al., 2010)

Sementara dalam penelitian ini permasalahan yang dihadapi adalah apakah kinerja guru berpengaruh terhadap motivasi belajar siswa kelas awal pada mata pembelajaran IPA berbasis pembelajaran jarakjauh (PJJ) di Sekolah Dasar Negeri 77 Kota Tengah Kota Gorontalo? Guru sangat berperan aktif dalam menciptakan proses pembelajaran dengan suasanan yang tenang, menyenangkan. Kondisi yang demikian menuntut aktivitas dan kreativitas guru, agar dapat menghasilkan tenaga pendidik yang kreatif, handal terlibat secara aktif baik mental, fisik maupun sosialnya dibutuhkan tenaga guru sekolah dasar yang sesuai dengan kompetensi pendidikannya yaitu menguasai bidang pengetahuannya dan menguasai keterampilan pedagogisnya dalam mengajar siswa sekolah dasar.

Aktivitas belajar mengajar sangat ditentukan oleh banyak faktor yaitu diantaranya faktor yang berasal dari dalam diri siswa dan faktor dari luar, faktor dari dalam yaitu motivasi, minat, dan pengetahuan yang dimiliki siswa berupa pengetahuan awal. Faktor dari luar berasal dari lingkungan siswa berupa, keluarga, kinerja guru, dan motivasi belajar siswa. Dari faktor-faktor tersebut faktor yang sangat mempengaruhi proses belajar mengajar pembelajaran IPA adalah motivasi belajar siswa (Susanto, 2012).

Dalam menghadapi COVID-19 merupakan Kejadian Luar Biasa (KLB) yang menjadi pusat perhatian pemerintah Indonesia dan dunia karena mengakibatkan tingginya angka kesakitan dan kematian. Maka Sekolah Dasar 77 Kota Tengah Kota Gorontalo memulainya dengan proses belajar mengajar jarak jauh yang dilakukan oleh guru dan siswa sejak Maret 2020. Yayan Alpian, (2021) PJJ adalah jenis pendidikan di mana peserta didik berjarak jauh dari pendidik, sehingga pendidikan tidak dapat dilakukan dengan cara tatap muka. Maka penyajian materi pembelajaran kepada peserta didik harus melalui media. Menurut surat edaran Mendikbud No. 4/2020 tentang pelaksanaan pendidikan di masa darurat covid-19 untuk menekan penyebaran virus covid-19 yaitu dengan menghilangkan sementara pembelajaran tatap muka dan dilakukan dengan pembelajaran Jarak Jauh (PJJ) (Kemdikbud RI, 2016; Kemdikbud, 2020).

Situasi ini tentunya membawa dampak pada kualitas pembelajaran, siswa dan guru yang sebelumnya berinteraksi langsung di dalam kelas sekarang harus berinteraksi dalam ruang virtual yang terbatas. Iklim belajar yang tercipta melalui pembelajaran jarak jauh juga mempengaruhi motivasi belajar siswa, jika dalam pembelajaran tatap muka di sekolah guru mampu menciptakan suasana kelas yang kondusif untuk menjaga motivasi belajar siswa (Sudjana, 2009). Dalam pembelajaran motivasi merupakan sesuatu yang dibutuhkan dalam melakukan aktivitas belajar IPA untuk mencapai tujuan pembelajaran. ( $\mathrm{Suh}$ a rni, 2019 ) Siswa belajar di rumah secara online karena didorong oleh kekuatan mentalnya, kekuatan mental berupa keinginan, perhatian, kemauan, atau cita-cita. Kekuatan mentallah yang mendorong terjadinya belajar secara jarak jauh tersebut sehingga menghasilkan motivasi.

Berdasarkan hasil observasi siswa kelas awal merasa motivasi belajar IPAnya rendah yang diduga akibat latar belakang dan karakteristik siswa yang beragam. Untuk memperoleh motivasi belajar yang baik maka siswa mengubah cara-cara belajarnya, dengan adanya dorongan yang berorientasi pada tujuan untuk memperoleh hasil belajar siswa pada 
pembelajaran IPA di kelas awal tersebut. Motivasi perlu didukung oleh beberapa faktor baik internal dalam diri siswa sendiri dan eksternal berupa dorongan yang berasal dari luar diantaranya fasilitas (internet yang memadai, laboratorium, sumber bacaan berupa buku, jurnal, majalah dan lain- lain), pujiaan, reward, dan hal-hal lain yang berkaitan dengan peningkatan motivasi belajar.

Siswa elas awal akan berhasil dalam belajar jika dalam dirinya sendiri ada keinginan untuk belajar. Keinginan atau dorongan untuk belajar dinamakan motivasi. Motivasi berasal dari kata motif yang dapat diartikan sebagai kekuatan yang terdapat dalam diri individu, yang menyebabkan individu tersebut bertidak atau berbuat (Farhah, Ahiri, \& Ilham, 2020). Nasrah, (2020) Motif adalah "A stete of behavior toward the in which arouses, maintains and direct behavior a goal."( Satu kekuatan dalam diri individu yang melahirkan, memelihara dan mengarahkan perilaku kepada suatu tujuan).

Menurut Sardiman, (2018)motivasi dapat diartikan sebagai daya penggerak yang telah menjadi aktif, atau serangkaian usaha untuk menyediakan kondisi-kondisi tertentu, sehingga seseorang mau dan ingin melakukan sesuatu, dan bila ia tidak suka, maka akan berusaha untuk meniadakan atau mengelakkan perasaan tidak suka itu. Jadi motivasi itu dapat dirangsang oleh faktor dari luar tetapi motivasi itu adalah tumbuh di dalam diri seseorang menurut (Slavin, 2018). Motivasi adalah unsur terpenting pengajaran yang efektif. Motivasi sebagai proses internal yang mengaktifkan, menuntun, dan mempertahankan perilaku dari waktu kewaktu, dapat disintesis bahwa motivasi belajar adalah daya dorong baik yang bersumber dari dalam diri siswa keas awal maupun dari luar yang menimbulkan proses belajar untuk mencapai tujuan belajar yaitu dengan indikator (1) adanya hasrat dan keinginan untuk melakukan kegiatan, (2) adanya dorongan dan kebutuhan melakukan kegiatan, (3) adanya harapan dan cita-cita, (4) penghargaan dan penghormatan atas diri, (5) adanya lingkungan yang baik, dan (6) adanya kegiatan yang menarik (Aurora \& Effendi, 2019).

Berkaitan dengan indikator pencapain tersebut maka dibutuhkan kinerja guru yang harus mampu melaksanakan tugas profesionalnya secara baik dan benar dalam upaya meningkatkan kinerja guru. Agar tercipta kinerja guru yang baik dalam proses belajar mengajar guru harus mampu melibatkan siswa pada awal proses belajar mengajar, yakni menarik perhatian siswa tentulah guru harus menguasai bahan pembelajaran, mampu mediaknosis tingkah laku siswa, mampu melaksanakanproses pembelajaran baik tatap muka dan jarak jauh, dan mampu mengevaluasi hasil belajar siswa yang merupakan bagian integral dalam pembelajaran ilmu pengetahuan alam diantaranya adalah faktor yang berpengaruh terhadap motivasi belajar siswa (Wardany, 2020).

Terciptanya motivasi belajar siswa yang baik sangat menunjang proses belajar mengajar berlangsung. Secara umum keberhasilan proses pembelajaran jarak jauh sangat ditentukan oleh beberapa komponen yaitu, baik yang berasal dari siswa, guru dan sarana prasarana berupa tersedianya jaringan internet ditempat siswa serta kurikulum yang dapat menunjang proses pembelajaran IPA secara jarak jauh. Komponen-komponen ini akan saling berkaitan antara yang satudengan yang lain. Siswa tanpa motivasi tidak akan terjadi proses pembelajaran, demikian juga siswa tanpa komponen yang lain tidak mungkin terjadi proses pembelajaran (Diana, Ahmad, \& Wahidy, 2020).

Berkaitan dengan masalah tersebut dibutuhkan kinerja guru sebab guru merupakan ujung tombak keberhasilan proses pembelajaran. Sebagai pendidik guru mengemban amanah untuk mengembangkan potensi yang dimiliki siswa kelas awal, baik dari aspek pengetahuan, keterampilan, dan sikap yang sesuai dengan tujuan yang telah ditetapkan. Mengajar atau yang lebih spesifik melakukan proses belajarmengajar jarak jauh bukanlah pekerjaan yang mudah oleh sebab itu haruslah direncanakan dan didesain sedemikian rupa mengikuti langkahlangkah dan prosedur pendidikan jarak jauh terlebih dahulu oleh guru sebelum memulai proses belajar mengajar, guru harus memiliki keterampilan dalam mengelola pembelajaran IPA berbasis PJJ agar dapat mencapai motivasi belajar siswa yang memuaskan sehingga berimbas terhadap tercapainya tujuan pembelajaran. 


\section{METODOLOGI}

Penelitian ini dilakukan dalam bentuk Survei, data dikumpulkan melalui siswa yang terpilih sebagai anggota sampel dengan menggunakan instrumen yang disusun khusus untuk penelitian ini, metode survei yang digunakan dalam penelitian ini adalah metode survei kausal yang sifatnya menjelaskan hubungan dengan teknik analisis jalur yang dapat mengestimasi pengaruh seperangkat variabel bebas (eksogen) terhadap variabel terikat (endogen) dalam hubungan sebab akibat.

Variabel dalam penelitian ini terdiri dari variabel bebas (eksogen) dan variabel terikat (endogen). Variabel eksogen berupa Kinerja guru (X). Sedangkan variabel terikat (endogen) yaitu berupa Motivasi Belajar $(\mathrm{Y})$. Populasi dan sampel dalam penelitian ini adalah seluruh siswa kelas awal SDN no. 77 Kota Tengah.

Data dikumpulkan dengan menggunakan instrumen dalam bentuk kuesioner. Instrumen-instrumen dari empat variabel yang disusun berdasarkan indikator variabel dan kisi-kisi. Instrumen tersebut disamping berisi pernyataan yang ada hubungannya dengan informasi yang ingin diperoleh sesuai indikator yang telah ditetapkan.

Pilihan jawaban pada instrumen menggunakan skala lima dengan rentang 1 sampai dengan 5 yang tersedia terdiri terdiri dari 5 (lima) option dengan menggunakan skala bertingkat (rating scale) 1,2,3,4,5. Instrumen didahului dengan menyusun kisi-kisi yang diturunkan dari kerangka berpikir. Sebelum instrumen digunakan terlebih dahulu diujicobakan, tujaunnya untuk mengetahui validitas dan reliabilitas. Instrumen penelitian diuji cobakan.

Selanjutnya, analisis data untuk menguji hipotesis digunakan dengan analisis deskriptif dan inferensial. Analisis deskriptif meliputi, menentukan mean, median, modus dan standar deviasi, serta memvisualisasikan data hasil penelitian dalam bentuk tabel distribusi frekuensi dan histogram. Adapun analisis inferensial berkaitan dengan hipotesis penelitian. Sebelum melakukan pengujian hipotesis, terlebih dahulu dilakukan pengujian normalitas dengan menggunakan Liliefors. Untuk pengujian hipotesis menggunakan statistik analisis jalur.

Analisis statistik yang sesuai untuk menguji pengaruh antar variabel dimana diantara variabel itu ada yang berperan sebagai variabel antara adalah analisis jalur (path analysis). Pengujian ini mempersyaratkan data berdistribusi normal dan model regresi linear. Pengujian normalitas data menggunakan galat taksiran regresi dengan memanfaatkan SPSS for Windows Versi 23 Uji Normalitas galat regresi pengaruh kinerja guru $(X)$ terhadap motivasi belajar siswa $(\mathrm{Y})$. Output hasil pengujian normalitas galat regresi pengaruh kinerja guru $(\mathrm{X})$ terhadap motivasi belajar siswa (Y) yaitu Hipotesis yang akan diuji dinyatakan sebagai berikut.

$\mathrm{H}_{\mathrm{o}}$ : Galat regresi berasal dari populasi yang berdistribusi normal

$\mathrm{H}_{1}$ : Galat regresi berasal dari populasi yang tidak berdistribusi Normal.

Kriteria pengujiannya adalah terima $\mathrm{H}_{\mathrm{o}}$ jika $\mathrm{L}_{\text {hitung }} \leq \mathrm{L}_{\text {tabel, }}$, dalam keadaan lain tolak $\mathrm{H}_{\mathrm{o}}$ pada taraf signifikansi $\alpha=5 \%$.

\section{HASIL DAN PEMBAHASAN}

Data hasil penelitian kinerja guru dikumpulkan melalui tes bentuk pilihan ganda yang berjumlah 25 butir soal. Berdasarkan hasil jawaban dari 35 responden (siswa) dan dengan menggunakan program SPSS for Window versi 23 diperoleh informasi seperti pada Tabel 1 dan Tabel 2 serta grafik pada gambar 1.

Tabel 1. Data tunggal hasil penelitian kinerja guru (x)

\begin{tabular}{llllllllllll}
\hline 46 & 50 & 51 & 55 & 63 & 65 & 67 & 73 & 77 & 85 & 94 & 100 \\
\hline 48 & 50 & 52 & 59 & 64 & 65 & 69 & 75 & 79 & 87 & 95 & 101 \\
\hline 50 & 50 & 55 & 59 & 64 & 67 & 69 & 77 & 85 & 92 & 97 & \\
\hline
\end{tabular}


Jumlah sampel (n) : 35

Skor maximum : $: 101$

Skor minimum $\quad: 46$

Rentang (R) : $101-46=55$

Banyaknya kelas $(\mathrm{K}) \quad=1+3,3 \log (35)=1+3,3(1,54)=6,10 \approx 6$

Panjang Kelas $\quad(\mathrm{P}) \quad=\frac{\mathrm{R}}{\mathrm{K}}=\frac{55}{6}=9,17 \approx 10$

Tabel 2 Daftar Distribusi Frekuensi Kinerja Guru

\begin{tabular}{|c|c|c|c|c|c|c|c|}
\hline No. & $\begin{array}{c}\text { Kelas } \\
\text { Interval }\end{array}$ & $\mathbf{f}_{\mathbf{i}}$ & $\mathbf{f}_{\text {relatif(\%) }}$ & $\mathbf{x}_{\mathbf{i}}$ & $\mathbf{f}_{\mathrm{i}} \cdot \mathbf{x}_{\mathbf{i}}$ & $\mathbf{x}^{2}$ & $f_{i} \cdot x_{i}^{2}$ \\
\hline 1. & $46-55$ & 10 & 28,57 & 50,5 & 505 & 2550 & 25502,5 \\
\hline 2. & $56-65$ & 7 & 20,00 & 60,5 & 423,5 & 3660 & 25621,75 \\
\hline 3. & $66-75$ & 6 & 17,14 & 70,5 & 423 & 4970 & 29821,5 \\
\hline 4. & $76-85$ & 5 & 14,29 & 80,5 & 402,5 & 6480 & 32401,25 \\
\hline 5. & $86-95$ & 4 & 11,43 & 90,5 & 362 & 8190 & 32761 \\
\hline 6. & 96-105 & 3 & 8,57 & 100,5 & 301,5 & 10100 & 30300,75 \\
\hline \multicolumn{2}{|r|}{$\sum$} & 35 & 100 & & 2417,5 & 35951,5 & 176408,8 \\
\hline
\end{tabular}
berikut.

Dari tabel diperoleh nilai rata-rata (mean), median (Me), dan modus (Mo) sebagai

$\overline{\mathrm{X}}=\frac{\sum x_{i} \cdot f_{i}}{\sum f_{i}}=\frac{2417,5}{35}=69,07$

Posisi Median berada pada interval $66-75$

$\begin{array}{lllll}\mathrm{B}=65,5 & \mathrm{P}=10 & \mathrm{n}=35 & \mathrm{~F}=17 & \mathrm{fi}=6\end{array}$

$M e=B+p\left(\frac{1 / 2^{n-F}}{f_{i}}\right)=65,5+10\left(\frac{17,5-17}{6}\right)=66,33$

Posisi Modus berada pada interval $46-55$

$\mathrm{B}=45,5 \quad \mathrm{P}=10 \quad \mathrm{n}_{1}=10-0=10 \quad \mathrm{n}_{2}=10-7=3$

$M o=B+p\left(\frac{n_{1}}{n_{1}+n_{2}}\right)=45,5+10\left(\frac{10}{10+3}\right)=53,19$

Standar deviasi

$\mathrm{SD}=\sqrt{\frac{\sum \mathrm{fi} . \mathrm{xi}^{2}-\frac{\left(\sum \mathrm{fi} . \mathrm{xi}\right)^{2}}{\mathrm{n}}}{\mathrm{n}-1}}=\sqrt{\frac{176408,8-\frac{2417,5^{2}}{35}}{35-1}}=16,65$

Varians

$\mathrm{SD}=\frac{\sum \mathrm{fi}_{\mathrm{xi}}{ }^{2}-\frac{\left(\sum \mathrm{fi} . \mathrm{xi}\right)^{2}}{\mathrm{n}}}{\mathrm{n}-1}=\frac{176408,8-\frac{2417,5^{2}}{35}}{35-1}=277,31$

Sebaran data kinerja guru berdasarkan tabel distribusi frekuansi seperti gambar 1. Tabel 2 memberikan informasi tentang hasil olahan data berdasarkan tabel distribusi frekuensi. Hasil output SPSS diperoleh rata-rata (mean) sebesar 69,07; nilai tengah data (median) sebesar 65,5; modus (mode) sebesar 53,19; dan standar deviasi sebesar 16,65. Jika diperhatikan letak rata-rata, median, dan modus dalam kurva normal maka data hasil kinerja guru cenderung rendah. 


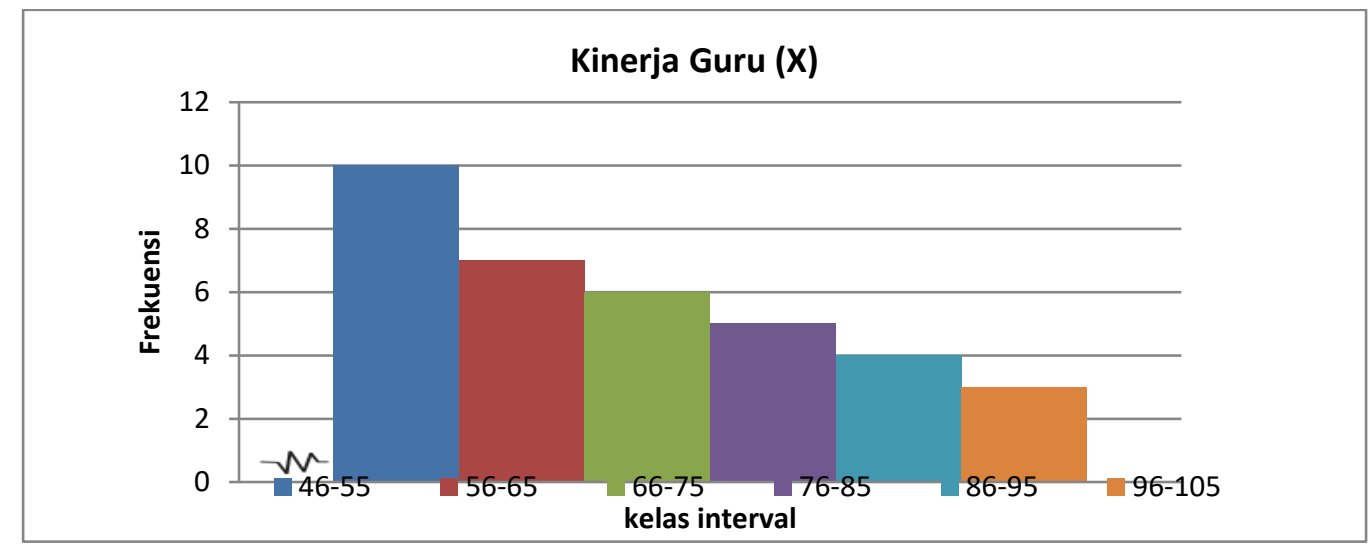

Gambar 1. Grafik Kinerja Guru

\section{Data Hasil Penelitian Motivasi Belajar Siswa (Variabel Y).}

Data hasil penelitian Motivasi Belajar Siswa dikumpulkan melalui tes bentuk pilihan ganda yang berjumlah 27 butir soal. Berdasarkan hasil jawaban dari 35 responden (siswa) dan dengan menggunakan program SPSS for Window versi 23 diperoleh informasi seperti pada Tabel 3 dan Tabel 4 serta grafik pada gambar 2 .

Tabel 4 Data tunggal hasil penelitian motivasi belajar siswa

\begin{tabular}{cccccccccccc}
\hline 61 & 68 & 78 & 86 & 93 & 95 & 97 & 99 & 104 & 107 & 112 & 120 \\
\hline 61 & 74 & 83 & 87 & 93 & 96 & 98 & 102 & 105 & 108 & 112 & 122 \\
\hline 65 & 75 & 85 & 90 & 93 & 97 & 98 & 102 & 106 & 110 & 114 & \\
\hline
\end{tabular}

$$
\begin{aligned}
& \text { Jumlah sampel (n) : : } 35 \\
& \text { Skor maximum } \quad: 122 \\
& \text { Skor minimum : } \quad 61 \\
& \text { Rentang }(\mathrm{R}) \quad: 122-61=61 \\
& \text { Banyaknya kelas }(\mathrm{K}) \quad=1+3,3 \log (35)=1+3,3(1,54)=6,10 \approx 6 \\
& \text { Panjang Kelas }(\mathrm{P}) \quad=\frac{\mathrm{R}}{\mathrm{K}}=\frac{61}{6}=10,17 \approx 11
\end{aligned}
$$

Tabel 4 Daftar Distribusi Frekuensi Motivasi Belajar Siswa

\begin{tabular}{cccccccc}
\hline No. & Kelas Interval & $\mathbf{f}_{\mathbf{i}}$ & $\mathbf{f}_{\text {relatif( }(\%)}$ & $\mathbf{x}_{\mathbf{i}}$ & $\mathbf{f}_{\mathbf{i}} \cdot \mathbf{x}_{\mathbf{i}}$ & $\mathbf{x}_{\mathbf{i}}{ }^{2}$ & $\mathbf{f}_{\mathbf{i}} \cdot \mathbf{x}_{\mathbf{i}}{ }^{2}$ \\
\hline 1. & $61-71$ & 4 & 11,43 & 66 & 264 & 4356 & 17424 \\
2. & $72-82$ & 3 & 8,57 & 77 & 231 & 5929 & 17787 \\
3. & $83-93$ & 8 & 22,86 & 88 & 704 & 7744 & 61952 \\
4. & $94-104$ & 10 & 28,57 & 99 & 990 & 9801 & 98010 \\
5. & $105-115$ & 8 & 22,86 & 110 & 880 & 12100 & 96800 \\
6. & $116-126$ & 2 & 5,71 & 121 & 242 & 14641 & 29282 \\
\hline & $\Sigma$ & 35 & 100 & & 3311 & 54571 & 321255 \\
\hline
\end{tabular}

Dari tabel diperoleh nilai rata-rata (mean), median (Me), dan modus (Mo) sebagai berikut.

$\overline{\mathrm{X}}=\frac{\sum x_{i} \cdot f_{i}}{\sum f_{i}}=\frac{3311}{35}=94,60$

Posisi Median berada pada interval $94-104$
$\mathrm{B}=93,5$
$\mathrm{P}=11$
$\mathrm{n}=35$
$F=15$
$\mathrm{fi}=10$ 
$M e=B+p\left(\frac{1 / 2^{n-F}}{f_{i}}\right)=93,5+11\left(\frac{17,5-15}{10}\right)=96,25$

Posisi Modus berada pada interval $94-104$

$$
\begin{aligned}
& \mathrm{B}=93,5 \quad \mathrm{P}=11 \quad \mathrm{n}_{1}=10-8=2 \quad \mathrm{n}_{2}=10-8=2 \\
& M o=B+p\left(\frac{n_{1}}{n_{1}+n_{2}}\right)=93,5+11\left(\frac{2}{2+2}\right)=99
\end{aligned}
$$

Standar deviasi

$$
\mathrm{SD}=\sqrt{\frac{\sum \mathrm{fi} . \mathrm{xi}^{2}-\frac{\left(\sum \mathrm{fi} . \mathrm{xi}\right)^{2}}{\mathrm{n}}}{\mathrm{n}-1}}=\sqrt{\frac{321255-\frac{3311^{2}}{35}}{35-1}}=15,37
$$

Varians

$$
\mathrm{SD}=\frac{\sum \mathrm{fi} \cdot \mathrm{xi}^{2}-\frac{\left(\sum \mathrm{fi} . \mathrm{xi}\right)^{2}}{\mathrm{n}}}{\mathrm{n}-1}=\frac{321255-\frac{3311^{2}}{35}}{35-1}=236,31
$$

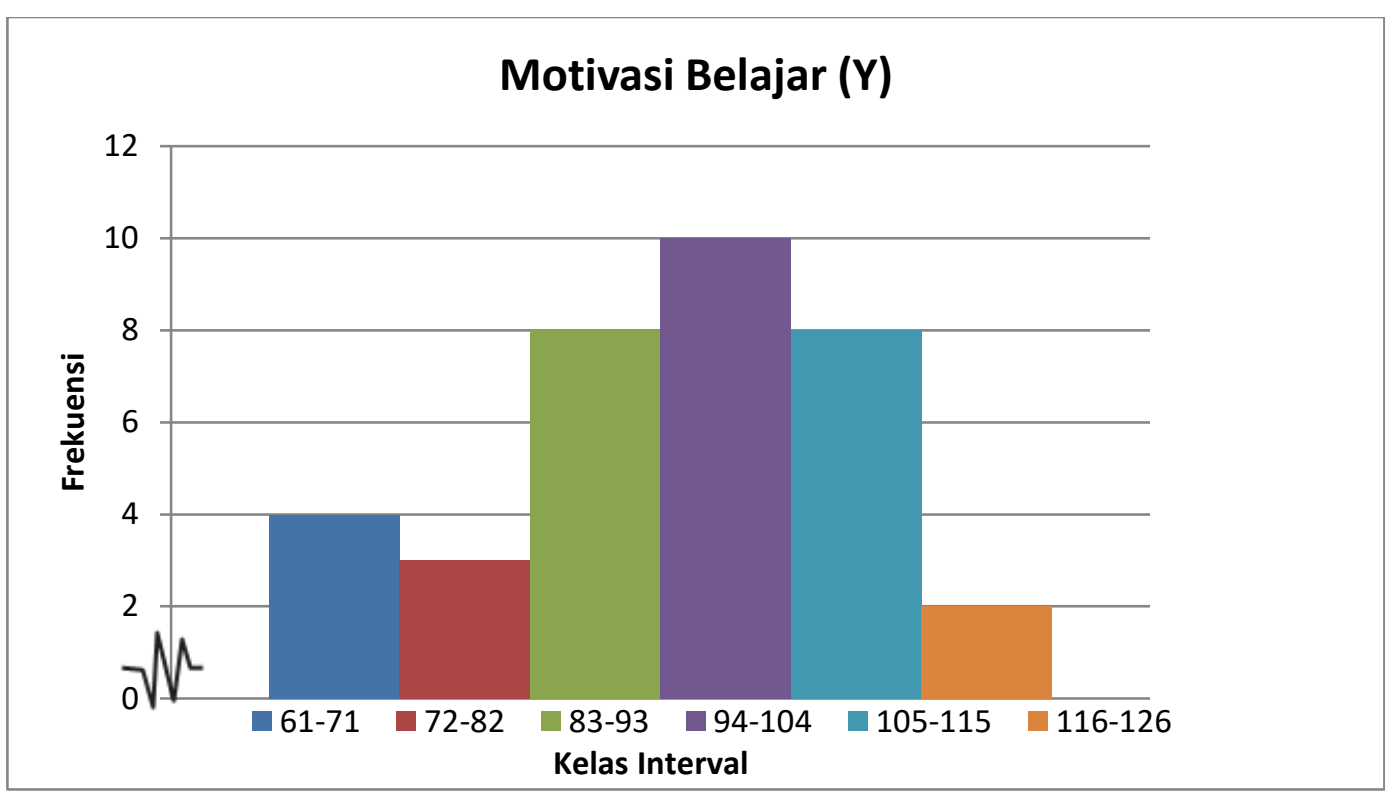

\section{Gambar 2. Histogram Motivasi Belajar siswa}

Tabel 4 memberikan informasi tentang hasil olahan data berdasarkan tabel distribusi frekuensi. Hasil output SPSS diperoleh rata-rata (mean) sebesar 94,60 nilai tengah data (median) sebesar 93,5; modus (mode) sebesar 99; dan standar deviasi sebesar 15,37. Jika diperhatikan letak rata-rata, median, dan modus dalam kurva normal maka data hasil kinerja guru cenderung tinggi.

Hipotesis penelitian yang diuji adalah "terdapat pengaruh langsung positif Kinerja guru terhadap motivasi belajar siswa kelas awal pada pembelajaran IPA berbasis pembelajaran jarak jauh di Sekolah Dasar Negeri 77 Kota Tengah Kota Gorontalo. Hasil pengujian menunjukkan bahwa hipotesis penelitian yang diajukan peneliti teruji kebenarannya. Ini berarti bahwa motivasi belajar siswa kelas awal pada pembelajaran IPA berbasis pembelajaran jarak jauh dipengaruhi/ditentukan oleh kinerja guru. Makin tinggi kinerja guru maka akan makin tinggi pula pencapaian motivasi belajar siswa kelas awal pada pembelajaran jarak jauh. 
Temuan ini menunjukkan bahwa eksistensi kinerja guru dipandang sebagai bagian yang paling penting dalam meningkatkan motivasi belajar pada pembelajaran IPA berbasis pendidikan jarak jauh (Megawanti, Megawati, \& Nurkhafifah, 2020). yang menyatakan bahwa kinerja guru adalahkemampuan untuk melakukan pekerjaan atau tugas yang dimiliki dalam menyelesaikan pekerjaan. Berkaitan dengan kinerja guru yang merupakan faktor penentu motivasi belajar dalam mencapai keberhasilan proses belajar mengajar. Wujud perilaku yang diharapkan yang dapat dijadikan acuan adalah kegiatan guru dalam proses belajar mengajar yaitu bagaimana seorang guru melakukan motivasi kepada siswa kelas awal baik dari perencanaan sebelum proses belajar mengajar berlangsung, melaksanakan kegiatan pembelajaran, dan menilai hasil belajar siswa. Motivasi adalah unsur terpenting pengajaran yang efektif. Motivasi sebagai proses internal yang mengaktifkan, menuntun, dan mempertahankan perilaku dari waktu kewaktu. Fadlilah, (2020) mengemukakan bahwa kecenderungan sukses ditentukan oleh motivasi, peluang, serta intensif; begitu pula sebaliknya dengan kecenderungan untuk gagal, motivasi berhubungan dengan keadaan emosi seseorang. Motivasi berprestasi dimiliki oleh setiap orang, sedangkan intensitasnya tergantung pada kondisi mental orang tersebut yang digunakan guru untuk memberikan stimulus kepada siswa agar produktif dalam belajar.

Dengan demikian dapat dipastikan bahwa siswa yang memiliki motivasi yang baik didukung oleh faktor eksternal dan internal berupa adanya hasrat dan keinginan untuk melakukan kegiatan, adanya dorongan dan kebutuhan melakukan kegiatan, adanya harapan dan cita-cita, adanya penghargaan dan penghormatan atas diri, adanya lingkungan yang baik, dan adanya kegiatan yang menarik yang dipastikan mahasiswa tersebut didukung oleh kinerja guru dalam menumbuhkan motivasi belajar siswa pada pembelajaran IPA berbasis pendidikan jarak jauh dimasa di Sekolah Dasar Negeri 77 Kecamatan Kota Tengah Kota Gorontalo

\section{SIMPULAN}

Terdapat pengaruh langsung positif kinerja guru terhadap motivasi belajar siswa kelas awal pada pembelajaran IPA berbasis pembelajaran jarak jauh. Ini menunjukkan bahwa motivasi belajar pada pembelajaran IPA dipengaruhi/ditentukan oleh kinerja guru, artinya makin tinggi kinerja guru dalam pembelajaran IPA maka makin tinggi pula pencapaian motivasi siswa kelas awal pada pembelajaran IPA berbasis pembelajaran jarak jauh (PJJ) di Sekolah Dasar Negeri 77 Kota Tengah Kota Gorontalo.

\section{UCAPAN TERIMA KASIH}

Terimakasih kepada seluruh pihak baik Kepala Sekolah SDN 77 Kota Tengah Kota Gorontalo yang telah mendukung dan memberikan kesempatan kepada penulis melakukan penelitian, siswa sebagai salah satu sumber informasi juga yang sangat mendukung hasil penelitian. Tak lupa juga ucapan Terima kasih Yang setinggi-tingginya kepada Jurnal Obsesi Jurnal Pendidikan Anak Usia Dini yang menjadi media bagi penulis dalam mempublish karya ini. Semoga hasil penelitian ini dapat terterima dan menambah khasanah pengetahuan serta bermanfaat khususnya bagi mahasiswa, guru dan dosen dan masyarakat umum pemerhati pendidikan pada Anak Usia Dini.

\section{DAFTAR PUSTAKA}

Aurora, A., \& Effendi, H. (2019). Pengaruh Penggunaan Media Pembelajaran E-learning terhadap Motivasi Belajar Mahasiswa di Universitas Negeri Padang. Jurnal Teknik Elektro Vokasional.

Cahyono, A. (2012). Analisa Pengaruh Kepemimpinan, Motivasi dan Budaya Organisasi terhadap Kinerja Dosen dan Karyawan di Universitas Pawyatan Daha Kediri. Jurnal Ilmu Manajemen Revitalisasi. 
Diana, R., Ahmad, S., \& Wahidy, A. (2020). Pengaruh Motivasi Kerja dan Komunikasi Interpersonal Terhadap Kinerja Guru. Jurnal Pendidikan Tambusai.

Fadlilah, A. N. (2020). Strategi Menghidupkan Motivasi Belajar Anak Usia Dini Selama Pandemi COVID-19 melalui Publikasi. Jurnal Obsesi : Jurnal Pendidikan Anak Usia Dini. https://doi.org/10.31004/obsesi.v5i1.548

Farhah, A., Ahiri, J., \& Ilham, M. (2020). Pengaruh Motivasi Kerja Dan Disiplin Kerja Terhadap Kinerja Karyawan. Jurnal Online Program Studi Pendidikan Ekonomi. https:// doi.org/10.36709/jopspe.v5i1.13326

Kemdikbud. (2020). Kemendikbud Terbitkan Pedoman Penyelenggaraan Belajar dari Rumah. Jakarta, 28 Mei 2020.

Kemdikbud RI. (2016). Kementerian Pendidikan dan Kebudayaan. Retrieved from http://kemdikbud.go.id/main/?lang=id

Megawanti, P., Megawati, E., \& Nurkhafifah, S. (2020). Persepsi Peserta Didik terhadap PJJ pada Masa Pandemi COVID-19. Jurnal Ilmiah Pendidikan.

Mudjihartono, P., Teknik, M., Universitas, I., Yogyakarta, A., Scorecard, B., \& Keputusan, S. P. (2010). Sistem Pendukung Keputusan Penilaian Kinerja Dosen Dengan Metode Balanced Scorecard ( Studi Kasus : Universitas Respati Yogyakarta ). Seminar Nasional Informatika 2010 (SemnasIF).

Nasrah, A. M. (2020). Analisis Motivasi Belajaar dan Hasil Belajar Daring Mahasiswa Pada Masa Pandemik Covid-19. Riset Pendidikan Dasar.

Sardiman, A. M. (2018). Interaksi dan Motivasi Belajar Mengajar (cetakan 24). In Jakarta: Rajawali Pers.

Slavin, R. E. (2018). Educational Psychology: theory and practice / Robert E. Slavin, Johns Hopkins University. In Pearson.

Sudjana, N. (2009). Penilaian Hasil Proses Belajar Mengajar. In Sinarbaru.

Suharni, P. (2019). Upaya Meningkatkan Motivasi Belajar Siswa. G-Couns: Jurnal Bimbingan Dan Konseling. https://doi.org/10.31316/g.couns.v3i1.89

Susanto, H. (2012). Faktor-Faktor Yang Mempengaruhi Kinerja Guru The Factors Of Affecting The Performance Of The Teachers ' Of State Vocational High School. Jurnal Pendidikan Vokasi,. https:// doi.org/10.21831/jpv.v2i2.1028

Wardany, D. K. (2020). Kontribusi Kepemimpinan dan Kompetensi Profesional Terhadap Kinerja Guru. Jurnal Madinasika Manajemen Dan Keguruan.

Yayan Alpian. (2021). Sosialisasi Peran Orang Tua Di Masa Pandemik Covid 19 Dalam Pembelajaran Daring Bagi Anak Usia Sekolah Dasar Desa Cikalongsari Karawang. Jurnal Buana Pengabdian, https://doi.org/10.36805/jurnalbuanapengabdian.v2i2.1278 